SEÇÃO TEMÁTICA: ADOLESCÊNCIA NA CIDADE: QUESTÕES PARA OS CAMPOS

DA PSICANÁLISE, EDUCAÇÃO E POLÍTICA

\title{
Uma Juventude à Flor da Pele: o dilema de adolescer ou adoecer
}

Edson Saggese ${ }^{1}$ 'Universidade Federal do Rio de Janeiro (UFRJ), Rio de Janeiro/RJ - Brasil

RESUMO - Uma Juventude à Flor da Pele: o dilema de adolescer ou adoecer. $\mathrm{O}$ crescimento das lesões de pele autoprovocadas e a elevação das taxas de suicídio em faixas etárias mais jovens indicam um profundo mal-estar no adolescer contemporâneo. A tendência a medicalização de diversos aspectos da vida tem produzido uma abordagem reducionista desses fenômenos, dificultando o estabelecimento de fronteiras entre o adolescer e o adoecer. A pandemia do Covid-19 acentuou o sofrimento psíquico entre os adolescentes. Como alternativa a medicalização das crises subjetivas é necessário dar voz aos jovens para que possam transformar a angústia e o desalento em participação ativa no processo de mudanças da sociedade. Palavras-chave: Adolescência. Medicalização. Psicanálise. Lesões Autoprovocadas. Covid-19.

ABSTRACT - Youth on Edge: the teenaging or sickening dilemma. The growth of self-inflicted skin lesions and the increase in suicide rates in younger age groups show a deep malaise in contemporary adolescents. The trend towards medicalization of various aspects of life has produced a reductionist approach to these phenomena, making it difficult to set boundaries between adolescence and illness. The Covid-19 pandemic accentuated the psychological distress among the adolescents. As an alternative to the medicalization of subjective crises, it is necessary to give a voice to the young people so that they can transform anguish and dismay into an active participation in the process of changing society.

Keywords: Adolescence. Medicalization. Psychoanalysis. Self-Inflicted injuries. Covid-19.

Educação \& Realidade, Porto Alegre, v. 46, n. 1, e109166, 2021 
Uma Juventude à Flor da Pele

\section{Introdução}

Ao falarmos de cortes autoprovocados na pele e de suicídio na adolescência, nos ocorrem as palavras de Lima Barreto (1988, p. 148), em $O$ cemitério dos Vivos, ao referir-se às várias e infinitas formas de que se reveste a loucura: "[...]é possível que os estudiosos tenham podido reduzi-las em uma classificação, mas ao leigo ela se apresenta como árvores, arbustos e lianas de uma floresta: é uma porção de cousas diferentes”. Utilizamos, nesse contexto, o termo loucura não como designação de distúrbio mental, mas na terceira acepção registrada pelo dicionário Houaiss (Houaiss; Villar, 2001, p. 1785): “[...] ato ou fala extravagante, que pode parecer desarrazoada; atitude, comportamento que denota falta de senso, de juízo, de discernimento (como pode cometer tais ${ }^{1}$ )". Essa ressalva é necessária pois tornou-se regra no estamento médico enquadrar os adolescentes que se cortam, falam sobre suicídio ou tentam o suicídio como portadores de transtornos mentais. Não podemos negar que, em alguns casos, exista a possibilidade de um diagnóstico psiquiátrico. Mas, na maioria das ocasiões, podemos pensar em atos ou falas desarrazoadas (ainda segundo Houaiss e Villar (2001): “[...] não racionais; dominadas pela emoção"). Essas falas ou atos não deixam de ser dignas de atenção e cuidados. Pelo contrário, a expansão desses eventos nos jovens causa preocupação e indicam um profundo malestar no adolescer contemporâneo.

Em abril de 2018, o suicídio de dois adolescentes, alunos de um tradicional colégio da elite paulistana, contribuiu para a comoção pública com o aumento de suicídios entre os jovens. A morte dos dois sucedeu-se num intervalo de apenas 15 dias, e a visibilidade dos eventos acirrou o debate para o qual acorreram psiquiatras, psicanalistas e educadores. Se a mobilização das escolas constitui uma preocupação legítima, as respostas encontradas nem sempre levam os educadores na direção que conduza à compreensão mais ampla das questões envolvidas. Ampliar a visão dos profissionais da educação em relação ao sofrimento psíquico dos jovens pode evitar um reducionismo que transforme pseudosoluções em novos problemas.

Por que não creditar o crescimento dos atos autoagressivos exclusivamente ao aumento da prevalência de distúrbios mentais? Precisamos apontar os limites da patologização e medicalização da adolescência porque a dor incontornável no processo de adolescer está recebendo como resposta padrão a rotulação como doença e a medicalização irresponsável, distorcendo os limites das intervenções médicas e expandindo a formação de carreiras precoces de doentes mentais.

A definição de medicalização compreende a expansão do controle da medicina sobre problemas relacionados à vida em geral como crises evolutivas, hábitos de consumo, tristeza, excesso de esforço no trabalho etc. Além dessa definição mais geral, pode-se acrescentar medicalização como o uso excessivo de medicamentos, seguindo a lógica de expandir diagnósticos e tratar com remédios esferas de problemas antes resolvidas sem a participação do profissional médico (Giddens; Sutton, 2017). 


\section{Adolescer ou Adoecer?}

Adolescer ou adoecer, essa é uma dicotomia a ser explorada quanto à saúde mental na adolescência. Estão em jogo questões ligadas à travessia da adolescência, à pesquisa das fronteiras entre o que seria o processo normal do adolescer e a possibilidade do desencadeamento de quadros psicopatológicos nesse período etário. A adolescência apresenta potencial de criar situações desestabilizadoras da economia psíquica: momento de definições diversas no campo sexual, profissional, familiar, ela coloca questões que alguns sujeitos não têm condição de contornar.

Adolescer significa entrar na fase da adolescência; estar em processo de crescimento. A etimologia latina remete a "[...] desenvolver-se, crescer, brotar, engrossar, fazer-se grande, fortificar-se”. Adoecer significa "[...] torna-se doente ou adoentado, debilitar-se, enfermar". Em sentido figurado pode ser "[...] adquirir e/ou apresentar defeito moral (adoecer de presunção, de vaidade, de soberba)". A etimologia latina remete a "[...] afligir-se, amargurar-se, magoar-se". (Houaiss; Villar, 2001, p. 88/89).

Enveredar pela distinção entre os termos adolescer e adoecer não é uma tarefa simplesmente linguística, não obstante as duas palavras soarem semelhantes. Explorar a diferença entre as duas etimologias nos conduz ao centro de uma questão controversa. Enquanto a importância dos problemas de saúde mental concernentes à adolescência e à juventude merece reconhecimento unânime, suas causas e soluções estão longe de produzir consenso. Adolescer e adoecer são frequentemente confundidos nos campos da saúde e da educação, com consequências relevantes para os jovens, suas famílias e instituições como a escola e a justiça.

Reformulando as perguntas em outros termos: como alguém preocupado com a adolescência contemporânea pode avaliar seus desdobramentos? Um novo terreno social interfere no seu brotar e crescer, e não identificamos corretamente as mudanças desse solo, elemento fundamental para entendermos o jovem de hoje? Há um adoecer moral, e a juventude pós-moderna perdeu a capacidade de descobrir caminhos para formar laços com o Outro? Fatores não totalmente claros produzem novas epidemias de doenças mentais no adolescente, e essas doenças precisam ser precocemente diagnosticadas e tratadas? Para formular respostas que nos orientem no processo de interagir com os jovens e adolescentes devemos, preliminarmente, nos posicionar quanto a estas perguntas.

Começamos por explorar as crises sociais contemporâneas enquanto capazes de gerar sofrimento psíquico. Grandes transformações tecnológicas pareciam possibilitar a melhora da vida em sociedade e as condições de trabalho e renda. Mas a noção de progresso se viu abalada pela exacerbação de antigos problemas e criação de novos. Piketty (2020) aponta dois deles, o aumento da desigualdade e o aquecimento global, que contribuem para um profundo questionamento da própria 
Uma Juventude à Flor da Pele

noção de progresso (p. 573). O abalo sofrido por essa noção, até recentemente tão valorizada na sociedade ocidental contemporânea, atinge diretamente a perspectiva de vida das novas gerações.

No contexto de mudanças sociais aceleradas, conflitos quanto às questões de gênero, trabalho, educação e família devem ser levados em conta se quisermos falar da saúde mental na adolescência. Antes de ser um período etário ou de uma crise do curso da vida, a juventude é hoje o campo privilegiado de experimento e sofrimento por encontrarse num mundo onde as marcas que poderiam orientar o percurso do sujeito foram apagadas. O que isso quer dizer? Com a modernidade das sociedades ocidentais, foram perdidos as demarcações e os ritos que indicavam um lugar no mundo para o indivíduo. Aliais, nas sociedades pré-modernas, nem de individuo poderíamos falar: tratava-se de membros de um conjunto social (clã, tribo ou casta) que atravessavam certos ritos de passagem para acederem a um lugar estável no seu grupo social (Saggese, 2001). Com as mudanças produzidas pela modernidade, outros indicadores de travessia, menos determinantes, tomaram o lugar daqueles pré-modernos para indicar os caminhos de passagem entre a criança e o adulto, criando o que denominamos adolescência. Dentre as contribuições para as transformações da estrutura etária do curso da vida, Ariès (1978) refere-se à organização escolar e à polarização da vida social no século XIX em torno da família. Quanto à escola, Ariès assinala que, como um local separado da família, ela se torna, mais do que apenas um lugar de aprendizado formal, o primeiro e mais importante espaço para socialização da criança, que antes era apenas função da família. É ela que permite ao aluno se defrontar com diversos modos de ser e conviver no mundo, para construir valores morais e sociais, importantes para sua identidade adulta.

A escola se torna um locus privilegiado onde se desenrola o projeto da modernidade que, rompendo com a tradição, obrigava o indivíduo a buscar seus próprios caminhos. Iniciou-se, mais marcadamente no século XX, a passagem por um período que chamávamos de crise da adolescência, que o psicanalista Erikson (1976) vai conceituar como uma moratória social, ou seja, uma fase etária na qual há uma espécie de licença da sociedade para não ser nem criança nem adulto.

Ao final do século XX, entramos em um período que muitos teóricos denominaram Pósmoderno (Lyotard, 1993): todas as verdades seriam relativas, com incredulidade em relação aos metarrelatos (Lyotard, p. xvi), ou seja, uma pulverização do saber ou um mercado de crenças contraditórias. Giddens (1991, p. 29) fala em desencaixe para se referir “[...] ao deslocamento das relações sociais de contextos locais de interação e sua restruturação através de extensões indefinidas de tempoespaço". O processo de individualização sofre acentuada mudança nas sociedades industriais tornando-se uma "[compulsão] pela fabricação, o autoprojeto e a autorepresentação, não apenas da própria biografia, mas também de seus compromissos e articulações à medida que as fases da vida mudam", conforme assinala Beck (Giddens; Lash; Beck, 2012, p. 32). 
Podemos traçar esse progressivo desencaixe e a necessidade de o jovem fabricar seu autoprojeto e sua autorepresentação, seguindo as pistas, sempre pioneiras, dos artistas. O grande escritor alemão da passagem entre os séculos XVIII e XIX, Goethe (1981, p. 51), escreveu esses versos na sua obra Fausto:

$$
\begin{aligned}
& \text { O que você herdou dos seus pais } \\
& \text { Conquista-o, para que te pertença } \\
& \text { O que não se aproveita, é um fardo pesado } \\
& \text { Apenas o que o momento cria, é o que pode aproveitar. }
\end{aligned}
$$

O verso pode ser interpretado como um estímulo ao jovem da modernidade, saído do mundo medieval fechado, para transformar o que recebera das gerações anteriores, atualizá-lo e tornar a herança da tradição útil para sua vida. Temos, nesse caso, um estímulo à rebeldia juvenil que aponta para a necessidade de não deixar que o passado se torne um fardo, realçando a importância de ver o momento em que se vive, com as transformações que foram trazidas para as novas gerações. Mas, atenção: o otimismo iluminista de Goethe referia-se a um mundo em que a transformação era vista como progresso. O progresso como esperança. $\mathrm{O}$ novo como a projeção de um futuro melhor. $\mathrm{O}$ vínculo com o passado, uma raiz que precisava de ar, luz e espaço para crescer. Relembremos o que foi dito antes sobre a etimologia latina de adolescer que remete a desenvolver-se, crescer, brotar, engrossar, fazer-se grande, fortificar-se. Crise de crescimento: essa poderia ser uma visão otimista da crise da adolescência. Mas é esse o panorama que pode ser visto hoje?

$\mathrm{O}$ jovem indaga-se sobre o valor do que herdou dos seus pais. A própria noção de herança dissolve-se no ar pós-moderno, sobretudo quanto à herança cultural, a herança de projetos de vida. A escola, instituição chave para a construção do futuro, está em questão frente às novas formas de aquisição de saber. Quando se questionava o valor do ensino presencial frente o que seriam as imensas possibilidades de adquirir conhecimento das fontes googleanas, o surgimento de uma pandemia mudou o panorama. Ronchi (2020) esclarece: "Se a escola fosse só transmissão do saber de uma fonte a um receptor, o online não seria uma cópia defeituosa da lição presencial, mas sua realização plena” (tradução nossa). No entanto, não foi isso o que ocorreu e sim a reafirmação da necessidade da presença viva do Outro como condição de uma transmissão. Continua Ronchi (2020): “A presença viva fez sentir toda sua relevância para a didática precisamente quando as condições objetivas a interditavam". Essa questão atinge diretamente os educadores, cuja presença como um Outro fora da esfera familiar mostrou-se essencial para o desenrolar do processo de aprendizado. Permanece, contudo, sem resposta qual o lugar que esse Outro do adolescente deveria ocupar, não sendo aquele da tradição.

Outra importante questão para qual a tradição não oferece respostas é a da identidade de gênero. Novamente, a escola está envolvida como campo de batalha onde se desenrola grande parte do conflito entre as atitudes conservadoras de parte da sociedade e as novas formas da 
juventude vivenciar a partilha dos sexos. A heteronormatividade parece ser um fardo sem utilidade, um empecilho à realização mais plena da sexualidade e da afetividade dos jovens. Uma crescente onda reacionária insurge-se contra o que chamam Ideologia de gênero. As críticas baseiam-se na ideia de que há uma ação deliberada para legitimar a noção de variabilidade quanto às identidades de gênero. Acusam a existência de complôs para incitar, sobretudo, as crianças e os jovens a aderirem à frouxidão identitária quanto ao gênero a que pertenceriam naturalmente. Esta suposta naturalização desconhece as influências sociais sobre a identidade de gênero. Ignoram que a oposição ao que é feminino e ao que é masculino não passa de uma construção ativa começada na infância. Quando se deseja elogiar uma menina diz-se que ela é uma princesa (ou que é bela, prendada e do lar), nunca que ela é uma guerreira. Ao menino, diz-se que é macho, com nítida conotação elogiosa, e evita-se afirmar que ele é delicado. Nas descrições de Butler (2004), gênero não é algo inerente ao corpo, mas uma categoria social instável, um desempenho que pode mudar com a transformação das sociedades.

Como contraponto à onda reacionária, as novas gerações de pais liberais pensam que podem evitar que seus filhos passem por todos os percalços pelos quais gerações anteriores passaram. Existe, no mundo contemporâneo, a exigência suplementar de ser politicamente correto, educar os filhos livres dos preconceitos e limitações que atingiram os pais. O sucesso e bem-estar também são obrigatórios e as crianças devem ser preparadas para alcançá-los. Os adolescentes devem passar incólumes por todos os riscos da descoberta, de um mundo mais vasto do que aquele que conheceram sob a supervisão dos pais. As escolas estão obrigadas a cuidar que as crianças e jovens não só aprendam, mas que sejam saudáveis, livres, e, no entanto, disciplinados. Uma legião de especialistas está de plantão para socorrer professores e pais quando as coisas ameaçam sair de controle: médicos, psicólogos, psicanalistas, fonoaudiólogos - interrompemos a lista sem esgotá-la.

A descrição acima certamente receberá críticas, pois a realidade da infância e juventude no Brasil pode ser bem outra: descaso, abandono e violência. Sim, as duas realidades convivem. Camadas médias e altas da sociedade brasileira enquadram-se na primeira descrição, enquanto uma parcela significativa da população infanto-juvenil na segunda. Boa parte das famílias brasileiras vive em condição de pobreza extrema e o Estado não lhes fornece mínimas condições para dar educação e cuidados de saúde a seus filhos. Mas, mesmo assim, muitas dessas crianças são, de alguma forma, cuidadas, ou seja, passam pelo escrutínio da polícia, são vistas por Varas da Infância e Juventude, conduzidas a instituições de reeducação ou de abrigo nas quais sua situação de vulnerabilidade ganha contornos psicopatológicos (Vicentin, 2010). Nessas instituições, também podem ser encontrados profissionais especializados, como médicos, psicólogos e outros. A diferença é a presença constante de agentes encarregados de manter a ordem, mesmo com métodos nada adequados a processos de reeducação. 
Qual seria o aspecto comum aos dois cenários esboçados? Arriscamos dizer que é a medicalização, com a atribuição de diagnósticos psiquiátricos cuja oferta é abundante, tanto nos manuais especializados, quanto na mídia e nas redes sociais. Claro que as avaliações das crianças e adolescentes nos dois cenários descritos não são semelhantes. Também a variedade de opções terapêuticas disponíveis em ambientes ricos e pobres não são as mesmas. Nas camadas superiores são comuns diagnósticos como Síndrome do Pânico ou Transtorno de Déficit da Atenção e Hiperatividade (TDAH), enquanto para os menos afortunados predomina Transtorno de Conduta ou Transtorno de Personalidade Antissocial. O arsenal de medicação disponível também é diverso quando estão em jogo camadas sociais diferentes. Para os privilegiados, remédios supostamente de última geração, desenvolvidos recentemente pelos laboratórios farmacêuticos com promessas sedutoras em suas bulas. Para os pobres, medicações mais antigas, cujas patentes já caíram, permitindo aos governos as adquirirem a baixo custo.

Os dois cenários são montados em dois diferentes palcos: o das escolas públicas e o das escolas privadas. Certamente, essa diferença não pode ser tomada de forma estereotipada, pois as escolas públicas não recebem exclusivamente alunos oriundos das camadas mais pobres da sociedade. Mas, como tendência geral, o país assiste há décadas à migração das camadas mais altas da sociedade para o ensino privado, fruto do desinvestimento do estado na educação pública.

As diferenças entre classes sociais e ambientes escolares não eliminam o crescimento universal dos diagnósticos psiquiátricos para crianças e adolescentes nem o alarmante aumento de prescrições e uso de psicofármacos como psicoestimulantes, tranquilizantes, antidepressivos e antipsicóticos. A difusão do uso de medicação vem acompanhada de justificativas científicas (ou pseudocientíficas) que poderiam causar espanto em um epidemiologista mais exigente. O diagnóstico de autismo, por exemplo, cresceu vinte vezes nas últimas duas décadas. O Transtorno Bipolar foi diagnosticado 40 vezes mais nos últimos dez anos que na década anterior (Frances, 2016). São doenças epidêmicas transmitidas por um microrganismo muito virulento como o coronavírus, ou esse aumento espantoso de transtornos psiquiátricos corresponde apenas ao alargamento injustificável de critérios diagnósticos?

O aumento também abusivo de diagnósticos e a consequente medicalização já seriam motivo de preocupação, mas a situação torna-se ainda pior quando verificamos que os transtornos mentais de crianças e adolescentes foram os que mais cresceram, e damos a palavra ao psiquiatra americano Allen Frances (2016, p. 124):

Quando o mercado de adultos pareceu saturado, os fabricantes de remédios expandiram sua demografia de clientes direcionando produtos para as crianças - não por acaso todas as epidemias recentes de transtornos psiquiátricos ocorreram entre os jovens. E crianças são clientes particularmente seletos - conquiste-as cedo e poderá têlas para sempre. 
Uma Juventude à Flor da Pele

Note-se que o Dr. Frances, que intitulou seu livro Voltando ao normal, está longe de ser um antipsiquiatra, tendo sido o coordenador da equipe responsável pela elaboração do DSM-IV, o mais influente manual diagnóstico de transtornos mentais do mundo, produzido pela $A s$ sociação Americana de Psiquiatria e, atualmente, revisto e aumentado na sua quinta versão. Mesmo uma figura de destaque do mainstream psiquiátrico parece assustado com a dimensão do que ajudou a criar.

As classificações psiquiátricas alcançaram, no presente, uma grande importância cultural. A força performativa de suas categorias determina identidades que são aceitas de bom grado pelos classificados. Ou seja, as pessoas pacificam-se por achar que encontraram num diagnóstico psiquiátrico uma explicação para seus problemas emocionais, que podem ser resolvidos se utilizarem a medicação correta. Como aponta Safatle (2016, p. 203):

Pois estar doente é, a princípio, assumir uma identidade com grande força performativa. Ao compreender-se como 'neurótico', 'depressivo' ou portador de 'transtorno de personalidade borderline', o sujeito nomeia a si através de um ato de fala capaz de produzir performativamente efeitos novos, de ampliar impossibilidades e restrições.

Essa força performativa identitária se implanta com a anuência das famílias e das escolas que podem, assim, desresponsabilizarem-se por eventuais fracassos de seus projetos educacionais. A assimilação por essas instituições das categorias diagnósticas como explicação só foi possível em razão da mudança no conceito de estigma que cercava a doença mental.

Tornou-se comum o psiquiatra ser procurado com o intuito de confirmar um diagnóstico autoformulado e prescrever uma determinada medicação previamente escolhida pelo demandante, em geral, com a ajuda do Dr. Google, como poderíamos chamar o grande conjunto de sites dedicados a questões de saúde. Nesses casos, parece haver uma reversão do processo de marginalização que seria conduzido, à revelia do sujeito, a partir do estigma da doença mental e a medicalização dos seus sofrimentos vitais.

O conceito de estigma foi desenvolvido principalmente por Goffman (1988) como uma marca de desvalorização das relações sociais do indivíduo, definida pela desqualificação da sua inserção social plena por parte dos outros membros da sociedade. $\mathrm{O}$ autor realça, entre outros contextos, o surgimento da estigmatização a partir de um diagnóstico médico, através da modificação da identidade de pessoas adoecidas, comprometendo sua aceitação plena na sociedade. No presente, o próprio jovem (sua família ou sua escola) torna-se o agente da rotulação. A demanda pela medicação passa a ser a sequência lógica da sua autoidentificação como pertencente a um determinado grupo: os bipolares, os hiperativos, os portadores de síndrome do pânico etc. Parece haver uma confiança irrestrita na ciência e na tecnologia, criando sujeitos que se descrevem em termos do funcionamento neuroquímico (tenho um déficit de serotonina, por isso sou deprimido; tenho déficit de atenção e 
hiperatividade - TDAH - por isso não consigo prestar atenção nas aulas e tiro notas baixas). A depressão, a ansiedade, a compulsão não necessitariam, segundo essas modernas concepções, de nenhuma elaboração psíquica, e sim de estratégias de controle do sofrimento baseadas em medicação. Fatores ambientais que contribuiriam para o sofrimento psíquico são desconsiderados, sejam eles conflitos familiares, escolas com projetos pedagógicos falhos ou crises socioeconômicas.

A partir das últimas décadas do século XX ocorreu uma maciça “[...] cerebralização do sofrimento psicológico” (Vidal; Ortega, 2019, p. 21). Em Somos nosso cérebro? os autores situam a questão numa perspectiva que se desloca da ciência para à genealogia histórica:

\begin{abstract}
Resumindo, como uma visão do ser humano, o sujeito cerebral não deriva nem do avanço neurocientífico nem de uma mutação biopolítica do final do século XX. Ambos são relevantes, mas, no que diz respeito à sua importância para a pessoalidade, são mais bem compreendidos em uma perspectiva histórica de longo prazo. Pois apenas essa perspectiva mostra que, ao contrário do que os neurocientistas costumam afirmar ou insinuar, a convicção de que somos nosso cérebro não é corolário de avanços neurocientíficos nem um fato empírico. Em vez disso é uma posição filosófica ou metafísica, mesmo que alguns aleguem ser determinada pela ciência, que depende de pontos de vista sobre o que é ser uma pessoa humana (Vida; Ortega, 2019, p. 42).
\end{abstract}

O filósofo Hacking (2009), que se autodenomina um nominalista dinâmico, ou seja, “[...] interessado em como nossas práticas de nomear interagem com as coisas que nomeamos", apresenta ideias interessantes sobre o que denomina inventar pessoas:

Não acredito que haja uma história geral a ser contada sobre inventar pessoas. Cada categoria tem sua própria história. Se quisermos apresentar uma estrutura parcial na qual descrever tais eventos, poderíamos pensar em dois vetores. Um é o vetor da rotulação a partir de cima, de uma comunidade de especialistas que criam uma 'realidade' que algumas pessoas adotam para si. Diferente desse é o vetor do comportamento autônomo da pessoa que foi assim rotulada, que pressiona para baixo, criando uma realidade que cada especialista tem que encarar (p. 128).

O que estaria ocorrendo no caso da difusão dos diagnósticos psiquiátricos, que teriam deixado o lugar de estigmas indesejáveis para serem acolhidos como um reconforto identitário? Parece haver um encontro bem-sucedido entre a "[...] rotulação a partir de cima, de uma comunidade de especialistas", com um grupo crescente de pessoas que aceitam a realidade do transtorno mental como uma âncora para sua identidade. Por tudo que já foi levantado, podemos inferir que, vivendo um período de intensa vacilação identitária, os jovens sejam mais vulneráveis à junção da rotulação psiquiátrica com a auto-rotulação. 


\title{
Cortes entre a Vida e a Morte
}

Criticar a medicalização da vida não significa negar o sofrimento psíquico da juventude contemporânea. Como já mencionamos, existe uma crescente preocupação com as tentativas de suicídio e outros atos autoagressivos nessa população. Num país como o Brasil, em que a mortalidade por causas externas entre os jovens é bastante elevada devido à alta taxa de homicídios, devemos recorrer a dados epidemiológicos para avaliar o real impacto do suicídio entre os jovens. Ribeiro e Moreira (2018, p. 2828) apresentam e comentam dados atualizados sobre o problema. Analisando a situação brasileira comparativamente com o cenário internacional, os autores constatam:

\begin{abstract}
Em comum aos estudos longitudinais analisados, observa-se o aumento dos coeficientes de mortalidade por lesões autoprovocadas no Brasil e aumento da participação de diferentes faixas etárias de adolescentes e jovens com um padrão de destaque. As séries mais robustas e de maior abrangência seguem a tradição da literatura especializada e os dados comparados internacionalmente com relação ao risco crescente para os mais jovens (grifo nosso).
\end{abstract}

Em levantamento sobre a demanda de atendimentos no Serviço de Psiquiatria da Infância e Adolescência do Instituto de Psiquiatria da Universidade Federal do Rio de Janeiro (SPIA/IPUB/UFRJ), a coordenadora do serviço constatou, na faixa entre 11 a 17 anos, um aumento nos casos de autoagressão e tentativas de suicídio (Brasil, 2018). Só no ano de 2018, entre 156 adolescentes que chegaram ao serviço, 18,6\% procuravam atendimento por conta de cutting e $9,3 \%$ por tentativas de suicídio. Esses números são os maiores da série histórica de demanda de atendimento no Serviço em relação a essas questões.

Uma pesquisa brasileira (Rheinheimer et al., 2015, p. 136) revela o crescimento do autoenvenenamento em indivíduos de 8 a 17 anos, no sul do país. Entre 2005 e 2012, a taxa de intentos suicidas por envenenamento em crianças e adolescentes passou de 25,12 para 35,24 por 100 mil habitantes. Mas não é só esse o dado mais relevante para as questões que exploramos. O que impressiona nestes casos é a grande utilização de psicofármacos: 23,47\% usaram antidepressivos e 20,76 \% usaram tranquilizantes. Ou seja, em quase metade dos casos o agente da tentativa de suicídio foi uma medicação que estaria sendo empregada para tratar transtornos mentais. Na falta de pesquisas mais específicas, o mínimo a ser dito é que o fácil acesso de crianças e adolescentes às medicações psicotrópicas pode não ser parte da solução, mas parte do problema.

A elevação das taxas de suicídio em faixas etárias mais jovens resulta em preocupação social com o destino da juventude que parece tão precocemente desiludida com a vida. Na ocasião da mencionada reação social ao suicídio sucessivo de dois adolescentes, na capital paulista, a jornalista Eliane Brum (2018), do El País, abordou a questão de maneira muito lúcida, passando a considerar o problema sob o ângulo coleti- 
vo, perguntando se não deveríamos nos espantar se, “[...] num mundo distópico houvesse menos jovens com dificuldade de encontrar sentidos diante do desespero". Seu arrazoado prossegue indagando sobre as relações entre o indivíduo e a sociedade: "Se cada caso é um caso, o significado de ser adolescente nessa época determinada não pode ser deletado de qualquer resposta que pretenda ser uma resposta. Aberta, em constante construção, mas uma resposta”.

Se um jovem faz um intento suicida, ingerindo, por exemplo, uma quantidade excessiva de remédios, vulgarizou-se a conclusão de que ele quer chamar a atenção. É o caso de realmente prestarmos atenção, pois há uma indicação de sofrimento que não podemos desprezar. Cabe a pergunta do porquê só ser possível essa estratégia para indicar ao outro a relevância do seu sofrimento. Tentativas de suicídio devem ser levadas a sério, mas nem sempre indicam que o jovem tem uma doença, que precisa ser tratado com remédios e longas intervenções psiquiátricas.

Nossas considerações anteriores nos levam a não encarar com surpresa as crescentes dificuldades na travessia da adolescência. Também não nos surpreende que os eventos de autoagressão e suicídio entre os adolescentes sejam apresentados como frutos da expansão de transtornos mentais na população jovem. Já discutimos os aspectos inerentes a esse tipo de leitura e os descaminhos para os quais nos conduzem. Esclarecendo ainda uma vez, a leitura de fenômenos sociais exclusivamente sob a ótica patologizante nos leva a mais e mais medicalização dos eventos vitais. O objetivo da crítica não é minar a confiança dos profissionais que lidam com os problemas da juventude. A intenção ao criticar a medicalização é traçar limites entre a esperança e o pensamento mágico, entre a confiança e a credulidade e entre a ciência e a impostura. Um limite que ajude a escola a repensar seu papel como coadjuvante do processo de medicalização da juventude. Pode-se dizer que, apesar de múltiplos desafios, a escola é um trunfo indispensável para o desenvolvimento psicossocial do aluno e, nesse processo, o $\mathrm{Ou}$ tro/professor tem um papel importante ao não contribuir para gerar um veredicto psicopatológico, mas ser uma referência importante na escuta das transformações identitárias que atravessam as novas gerações.

\section{Adolescência, a Dor e os Veredictos do Outro}

Não podemos contradizer nossas afirmações iniciais, inspiradas em Lima Barreto (1988), que apontam os atos de autoagressão como uma porção de cousas diferentes. Essa opção se refere a recusa de participar do reducionismo classificatório sem, contudo, deixar de examinar com as lentes da teoria psicanalítica certas linhas de força que conduzem a expressão atual do sofrimento psíquico. Para isso, vamos pinçar alguns relatos, trazidos por adolescentes ${ }^{1}$ em análise, que podem fornecer algumas pistas para entendermos as questões envolvidas nesses atos. São questões metapsicológicas que não tem a pretensão de esgotar o assunto, mas sim ilustrar a existência de outros caminhos de compreensão do problema para além dos diagnósticos psiquiátricos. O objetivo 
Uma Juventude à Flor da Pele

é mostrar o quanto pode ser reducionista a atribuição de um diagnóstico para explicar atos mais complexos que podem ocorrer tanto no âmbito da família quanto da escola.

A mãe de Carla diz, após a filha ter exagerado na quantidade de sal na comida: você não presta para nada. Carla vai imediatamente para o banheiro e corta-se no dedo com uma gilete. Afirma que queria diminuir a dor, passar a dor de um lugar para outro.

Em Além do princípio do prazer, Freud (1986d, p. 29-30) aborda o desprazer produzido pela dor corporal, apontando que a proteção antiestímulo do aparelho psíquico foi perfurada. Conjectura, então, sobre a reação da vida psíquica frente a essa intrusão:

De todas as partes se mobiliza a energia de investimento a fim de criar, em torno do ponto de intrusão, uma investidura energética de nível correspondente. Se produz um enorme 'contrainvestimento' em favor do qual se empobrecem todos os outros sistemas psíquicos, de sorte que o resultado é uma extensa paralisia ou rebaixamento de qualquer outra operação psíquica (Tradução nossa do espanhol).

Nos interessa para a reflexão sobre o cortar-se a questão do $r e$ baixamento de qualquer outra operação psíquica. Poderíamos traduzir esse rebaixamento como impedimento do pensar, como interrupção do encadeamento significante que poderia constituir um trilhamento simbólico para o conflito psíquico. $\mathrm{O}$ efeito paralisante da dor sobre o aparelho psíquico pode ser o efeito mais imediato do corte. Queremos contrastar esse efeito justamente com outra leitura que veria o cortar-se como uma metáfora do sofrimento psíquico. Não há, a nosso ver, possibilidade metafórica, pois o efeito da dor do corte é exatamente a paralisia momentânea de qualquer possibilidade de inscrição na linguagem.

Freud (1986f, p. 160) retoma a problemática da dor corporal, agora incluindo o viés do narcisismo, para refrasear o que havia afirmado no texto que acabamos de citar:

\begin{abstract}
À raiz da dor corporal gera-se um investimento elevado, que se deve chamar narcisista, do lugar doloroso do corpo; esse investimento aumenta cada vez mais e exerce sobre o eu um efeito de esvaziamento, por assim dizer (Tradução nossa do espanhol).
\end{abstract}

O efeito da dor produzida pelos cortes na pele é o esvaziamento do eu impedindo o registro da angústia que, ainda que produzida por um excesso pulsional, deve ser registrada por um eu que, nas palavras de Freud, encontra-se paralisado, com sua possibilidade de operação psíquica rebaixada. Um órgão, a pele, através de suas numerosas terminações nervosas, se encaixa bem nesse exemplo da ação da dor sobre o aparelho psíquico. O termo pseudopulsão (um hápax na sua obra?), utilizado por Freud (1986c, p. 141) no artigo A repressão, realça a importância do efeito da dor como estímulo externo para desencadear um estímulo interno sobre o eu, que se concentraria na reação a essa fon- 
te, paralisando sua capacidade de reagir a outros estímulos capazes de gerar angústia. A primeira função dos cortes seria aplacar, com a dor física, a dor moral difícil de processar. Passar a dor de um lugar para outro, nas palavras de Carla.

A mãe de Joana a repreende asperamente por alguma falha ao cuidar dos irmãos menores e da casa. A adolescente afirma que o balde transbordou - essa é sua explicação para o fato de ter se cortado seriamente, provocando uma hemorragia. Ela diz que procurava ser certinha para agradar a mãe. Como os cortes sangravam muito, pediu ajuda da mãe, que se recusou a levá-la ao hospital por medo das autoridades lhe retirarem a guarda da filha.

Independente da gravidade das consequências, aparecem nas histórias das adolescentes ${ }^{2}$ em análise relatos sobre palavras vindas de alguém significativo e que induziram uma passagem, quase imediata, a atos violentos contra elas mesmas. Como entender essa relação?

Partindo da angústia de morte da melancolia, Freud (1986e) aponta para a explicação da radical renuncia à vida que ocorre no $e u$ quando da perda do amor: "Com efeito, viver tem para o eu o mesmo significado que ser amado: quer ser amado pelo supereu, que também nisso se apresenta como sub-rogado do isso" (p. 58, tradução nossa do espanhol). Essa estreita relação entre ser amado e a sobrevivência do eu pode ser compreendida traçando as origens do supereu. Freud (1986g, p. 120) segue a trilha desde o desamparo e dependência da criança até o estabelecimento da instância crítica. Essa trilha passa pela "[...] [angústia] frente a perda do amor". Para esse ser desvalido, o risco se apresenta como insuperável:

Se perde o amor do outro, do qual é dependente, fica também desprotegido contra perigos diversos, sobretudo frente ao perigo que esse alguém tão poderoso lhe demonstre a superioridade em forma de castigo (Tradução nossa do espanhol).

O caminho torna-se mais tortuoso quando a autoridade desse outro “[...] é internalizada pelo estabelecimento de um supereu (p. 121). Além da internalização desse outro, Freud (1986g, p. 121-122) vai apontar uma peculiaridade da consciência moral que contraria o senso comum:

[se] comporta com severidade e desconfiança tanto maiores quanto mais virtuoso é o indivíduo, de maneira que precisamente os que atingem maior santidade são os que mais acerbamente se recriminam da sua condição pecaminosa (Tradução nossa do espanhol).

Se a palavra, amplificada pelos poderes do supereu, ganhar um aspecto ameaçador, o que de particular no adolescente poderia acentuar o impacto do que é escutado como insulto ou reprimenda?

O professor de história quer discutir com a turma questões de gênero. Pedro (16 anos), um dos alunos, demonstrava sua angústia ao pen- 
sar e falar sobre a sua sexualidade e sua insatisfação por ter que ir para a escola onde o assunto estava sendo abordado. $\mathrm{O}$ adolescente relatou à terapeuta sentir atração por meninos e tinha receio de que as pessoas lhe perguntassem sobre a sua sexualidade. Entrou em sério conflito com o professor, próximo ao confronto físico, supondo que ele começaria a lhe fazer perguntas de cunho pessoal, sobre a sua sexualidade.

Soler (2018) esclarece um pouco mais quanto às relações entre o adolescente e o Outro, chamando de vereditos do Outro as palavras em que se atribui algo ao sujeito. Esses significantes tornam-se injuriosos quando um sujeito se percebe diverso da qualificação que lhe é lançada, mas não sabe em que lugar identitário se colocar. Soler (2018) completa:

Assim, a afirmação vinda do Outro, familiar ou social, pode fazer surgir espontaneamente para um sujeito a questão de sua verdadeira identidade. Esse fenômeno se produz eletivamente na adolescência, ainda que não exclusivamente, e se compreende o porquê. É que a adolescência é um tempo no qual o estatuto profissional, familiar, às vezes sexual, que assenta a identidade social de cada um está em suspenso (p. 18).

Essa vacilação das identificações, própria da adolescência, poderia amplificar a incidência do poder das palavras sobre o jovem. Ou ainda, faria acentuar a potência dessa voz que o amarra ao Outro, levandoo à submissão ou à recusa, marcada por atos radicais, em continuar a escutá-la. A psicanálise nos ajuda desvendar os marcos da constituição do sujeito e sua posição em relação ao Outro, permitindo extrair elementos para ampliar nosso conhecimento sobre a subjetividade dos adolescentes e sua relação com a produção de sintomas de autoagressão. Na escola, há um encontro com alguém que toma o lugar de um Outro privilegiado: o professor. Em um texto de 1914, Freud descreve a relação entre os alunos e os mestres:

No fundo, sentíamos grande afeição por eles, se nos davam algum fundamento para ela, embora não possa dizer quantos se davam conta disso. Estávamos, desde o princípio, igualmente inclinados a amá-los e a odiá-los, a criticá-los e a respeitá-los (Freud, 1986b, p. 249).

Relendo as palavras de Freud após mais de um século e de complexas mudanças sociais, não podemos endossá-las ipsis litteris, algo, entretanto, permanece da posição do aluno frente ao mestre. Mesmo em tempos em que o lugar de saber é constantemente questionado, o crescimento da errância identitária entre os jovens não elimina a força de um veredito do Outro proferido por um professor, antes o amplifica seja na dimensão do ódio, seja na do amor.

\section{Com a Palavra o Futuro}

Se há uma juventude à flor da pele, somos levados a crer que há uma sociedade também à flor da pele. Não podemos dissociar o sofrimento psíquico dos adolescentes e jovens das condições gerais da época 
na qual vivem. Em todos os sentidos, a adolescência guarda relação com a sociedade. Seja na sua constituição enquanto período etário crítico, seja na resposta, sob a forma de medicalização, que a vida contemporânea reserva ao sofrimento do jovem. A carência de trilhas simbólicas para conduzir a alguma estabilização identitária permitiu a abertura da larga avenida da patologização da vida. Para essa construção, confluem interesses econômicos que podem se desdobrar da economia psíquica àquela verdadeiramente monetária. Essa associação nos leva a valorizar as intervenções a serem feitas na economia psíquica enquanto pensamos também nas mudanças sociais mais amplas. Podem ainda ser válidas as palavras que Freud pronunciou em 1910 (Freud, 1986a, p. 142, tradução nossa do espanhol), como parte do seu discurso no $2^{\circ}$ Congresso Internacional de Psicanálise, fazendo a defesa do potencial transformador da psicanálise:

$$
\begin{aligned}
& \text { Porém eis aqui o principal: todas as energias que hoje se } \\
& \text { dilapidam na produção de sintomas neuróticos a serviço } \\
& \text { de um mundo de fantasia isolado da realidade efetiva con- } \\
& \text { tribuirão para reforçar, caso não se possa utilizar agora } \\
& \text { mesmo essas energias em proveito da vida, o clamor que } \\
& \text { demanda aquelas alterações da nossa cultura nas quais } \\
& \text { discernimos a única salvação para as gerações futuras. }
\end{aligned}
$$

As grandes transformações que vêm ocorrendo nas últimas décadas produziram uma espécie de adolescência generalizada. $\mathrm{O}$ que queremos dizer com isso? Que a situação de passagem, de desestabilização identitária, de desenraizamento da tradição não atinge somente aqueles que atravessariam uma crise evolutiva. Pais, professores e outras figuras que encarnavam o Outro contra o qual as novas gerações deviam se bater para conquistar a independência, não têm mais condições de representar as marcas da tradição a partir da qual se formaria o futuro. Todos partilham o mesmo sentimento de incerteza, de desencaixe, ou seja, de interações globais e instantâneas que subvertem as noções de espaço e tempo.

Nem precisaríamos da pandemia do Covid-19 para constatar a fragilidade da posição do homem contemporâneo frente às perspectivas quanto ao futuro. Mas sua ocorrência, reforça o juízo que "Na ordem maior das coisas, nós somos apenas uma espécie sem especial importância” (Zizek, 2020, p. 13. Tradução nossa). A afirmação não traz uma nova visão cosmológica, mas tira a ideia do círculo dos intelectuais que discutem as teorias Darwinianas para o cotidiano das multidões, que olham ora com esperança para os poderes da ciência, ora negam a existência do perigo evidente.

Mesmo antes de pesquisas mais acuradas já surgem as afirmações que à epidemia virótica se seguirá uma epidemia de transtornos mentais (Guessoum et al, 2020). São elencados os diagnósticos que estarão mais em voga (transtorno de stress pós-traumático, transtornos de ansiedade, transtornos depressivos estão entre os mais votados). Quem sabe, junto com as tão esperadas vacinas, os laboratórios farmacêuticos 
Uma Juventude à Flor da Pele

irão inundar o mercado com novos e antigos psicofármacos, resultando a pandemia em novo incentivo para o processo de medicalização da vida.

Como reagirá de fato a juventude? Já abordamos o poder das palavras sobre $\mathrm{o}$ adolescente, mas esse poder é ambivalente: ainda que o amarre ao Outro, também pode despertar uma recusa radical em continuar a ouvi-las. As vozes da pandemia soarão como desalento ou como despertar? Os cortes na pele que os adolescentes executam são manifestações de uma angústia que, não encontrando voz para expressá-la, convida a dor a ocupar seu lugar. A situação limite a que fomos conduzidos pede respostas não habituais, incluindo a reforma da sociedade desigualitária em que vivemos e a mudança da relação destruidora que estabelecemos com a natureza. Pode ser que os jovens emprestem sua voz à reivindicação de mudanças e a angústia encontre um caminho para fluir em palavras.

Recebido em 12 de novembro de 2020 Aprovado em 30 de março de 2021

\section{Notas}

1 Os nomes são fictícios, as situações reais.

2 A referência no feminino reflete o maciço predomínio de adolescentes do gênero feminino na procura de atendimento, a partir de atos autoagressivos.

\section{Referências}

ARIÈS, Philippe. História Social da Criança e da Família. Tradução: Dora Flaksman. Rio de Janeiro: Guanabara,1978.

BRASIL, Heloisa Helena Alves. Demanda de Atendimentos no Ambulatório do Serviço de Psiquiatria da Infância e Adolescência do Instituto de Psiquiatria da UFRJ. In: CONFERÊNCIA NO CENTRO DE ESTUDOS DO INSTITUTO DE PSIQUIATRIA DA UFRJ, 2018, Rio de Janeiro. Anais... Rio de Janeiro: UFRJ, 2018.

BRUM, Eliane. O Suicídio dos que Não Viram Adultos nesse Mundo Corroído, El País, 16 jun. 2018. Disponível em: <https://brasil.elpais.com/brasil/2018/06/18/ opinion/1529328111_109277>. Acesso em: 04 nov. 2018.

BUTLER, Judith. Undoing Gender. New York: Routledge, 2004.

ERIKSON, Erik Homburger. Identidade, Juventude e Crise. Tradução: Álvaro Cabral. Rio de Janeiro: Zahar, 1976.

FRANCES, Allen. Voltando ao Normal: como o excesso de diagnósticos e a medicalização da vida estão acabando com a nossa sanidade e o que pode ser feito para retomarmos o controle. Tradução: Heitor M. Correa. Rio de Janeiro: Versal, 2016.

FREUD, Sigmund. Las Perspectivas Futuras de la Terapia Psicanalítica. Tradução: José L. Etcheverry. In: FREUD, Sigmund. Obras Completas. Vol. XI. Buenos Aires: Amorrortu, 1986a. [1910]

FREUD, Sigmund. Sobre la Psicologia del Colegial. Tradução: José L. Etcheverry. In: Obras Completas. Vol. XIII. Buenos Aires: Amorrortu, 1986b. [1914]

FREUD, Sigmund. La Represión. Tradução: José L. Etcheverry. In: FREUD, Sigmund. Obras Completas. Vol. XIV. Buenos Aires: Amorrortu, 1986c. [1915] 
FREUD, Sigmund. Más allá del Principio de Placer. Tradução: José L. Etcheverry. In: FREUD, Sigmund. Obras Completas. Vol. XVIII. Buenos Aires: Amorrortu, 1986d. [1920]

FREUD, Sigmund. El Yo y el Ello. Tradução: José L. Etcheverry. In: FREUD, Sigmund. Obras Completas. Vol. XIX. Buenos Aires: Amorrortu, 1986e. [1923]

FREUD, Sigmund. Inhibicion, Sintoma y Angustia. Tradução: José L. Etcheverry In: FREUD, Sigmund. Obras Completas. Vol. XX. Buenos Aires: Amorrortu, 1986f. [1926]

FREUD, Sigmund. El Malestar em la Cultura. Tradução: José L. Etcheverry. In: FREUD, Sigmund. Obras Completas. Vol. XXI. Buenos Aires: Amorrortu, 1986g. [1930]

GIDDENS, Anthony; SUTTON, Philip. Conceitos Essenciais da Sociologia. Tradução: Claudia Freire. São Paulo: Unesp, 2017.

GIDDENS, Anthony. As Consequências da Modernidade. Tradução: Raul Fiker. São Paulo: Unesp, 1991.

GIDDENS, Anthony; LASCH, Scott; BECK, Ulrich. Modernização Reflexiva política, tradição e estética na ordem social moderna. Tradução: Magda Lopes. São Paulo: UNESP, 2012.

GOETHE, Johann Wolfgang von. Fausto. Tradução: Jenny Klabin Segall. Belo Horizonte: Itatiaia, 1981.

GOFFMAN, Erving. Estigma-Notas Sobre a Manipulação da Identidade Deteriorada. Tradução: Márcia Bandeira de Mello Leite Nunes. Rio de Janeiro: Livros Técnicos e Científicos, 1988.

GUESSOUM, Sélim Benjamim; LACHAL, Jonathan; RADJACK, Rahmeth; CARRETIER, Emilie; MINASSIAN, Sevan; BENOIT, Laelia; MORO, Marie Rose. Adolescent Psychiatric Disorders During the COVID-19 Pandemic and Lockdown. Psychiatry Research, 291, 113264. Disponìvel em: <https://doi. org/10.1016/j.psychres.2020.113264>. Acesso em: 22 out. 2020.

HACKING, Ian. Ontologia Histórica. Tradução: Leila Mendes São Leopoldo: Unisinos, 2009.

HOUAISS, Antônio; VILAR, Mauro de Salles. Dicionário Houaiss da Língua Portuguesa. Rio de Janeiro: Objetiva, 2001.

LIMA BARRETO, Afonso Henriques. Diário do Hospício. O cemitério dos vivos. Rio de Janeiro: Secretaria Municipal de Cultura, 1988.

LYOTARD, Jean-François. O Pós-Moderno. Tradução: Ricardo Côrrea Barbosa. Rio de Janeiro: José Olympio, 1993.

PIKETTY, Thomas. Capital e Ideologia. Tradução: Dorothée de Bruchard e Maria de Fátima do Couto. Rio de Janeiro: Intrínseca, 2020.

RHEINHEIMER, B.; KUNZ, M.; NICOLELLA, A.; BASTOS, T. Trends in Self-Poisoning in Children and Adolescents in Southern Brazil between 2005 and 2013. European Psychiatry, v. 30, n. 8, Supplement, November 2015. Disponível em $<$ https://doi.org/10.1016/j.eurpsy.2015.09.266>. Acesso em: 18/10/2020.

RIBEIRO, José Mendes; MOREIRA, Marcelo Rasga. Uma Abordagem sobre o Suicídio de Adolescentes e Jovens no Brasil. Ciência \& Saúde Coletiva, Rio de Janeiro, v. 23, n. 9, p. 2821-2834, set. 2018. Disponível em: <http://www.scielo. br/scielo.php?script=sci_arttext\&pid=S141381232018000902821\&lng=pt\&nrm= iso>. Acesso em: 04 nov. 2018 
RONCHI, Rocco. Didattica del Vírus. Doppiozero I 15 settembre 2020. Disponível em: <https://www.doppiozero.com/materiali/didattica-del-virus $>$. Acesso em: 18 set. 2020.

SAFATLE, Vladimir. O Circuito dos Afetos: corpos políticos, desamparo e o fim do indivíduo. Belo Horizonte: Autêntica, 2016.

SAGGESE, Edson. Adolescência e Psicose: transformações sociais e os desafios da clínica. Rio de Janeiro: Companhia de Freud, 2001.

SOLER, Colette. Rumo a Identidade. Tradução: Sônia Magalhães. São Paulo: Aller, 2018.

VICENTIN, Maria Cristina Gonçalves. Os 'Intratáveis’: a patologização dos jovens em situação de vulnerabilidade. In: CONSELHO Regional de Psicologia de São Paulo; GRUPO Interinstitucional Queixa Escolar (Org.). Medicalização de Crianças e Adolescentes. Conflitos silenciados pela redução de questões sociais a doenças de indivíduos. São Paulo: Casa do Psicólogo, 2010.

VIDAL, Fernando; ORTEGA, Francisco. Somos Nosso Cérebro? Tradução: Alexandre Martins. São Paulo: N-1 Edições/Hedra, 2019.

ZIZEK, Slavoj. Pandemic! Covid-19 shakes the world. New York: Polity Press, 2020.

Edson Saggese é psicanalista e psiquiatra. Professor da Universidade Federal do Rio de Janeiro, Instituto de Psiquiatria (IPUB/UFRJ). Coordenador do laboratório de pesquisa ProAdolescer. Autor dos livros: Adolescência e Psicose: transformações sociais e os desafios da clínica; Proadolescer: Pesquisa e Clínica com adolescentes na rede de saúde mental e Juventude e Saúde Mental: a especificidade da clínica com adolescentes.

ORCID: http://orcid.org/0000-0003-3775-9566

E-mail: edsonsaggese@gmail.com

Editora-Responsável: Fabiana de Amorim Marcello

Este é um artigo de acesso aberto distribuído sob os termos de uma Licença Creative Commons Atribuição 4.0 Internacional. Disponível em: <http:// creativecommons.org/licenses/by/4.0>. 